\title{
1. The Antitrust Damages Directive - much ado about nothing?
}

\section{Sebastian Peyer*}

\begin{abstract}
This chapter examines some of the key features of the EU Directive on antitrust damages actions. The Damages Directive aims to ensure effective private enforcement by facilitating claims in the courts of the EU Member States. However, the proposed measures do not address pressing issues such as claim aggregation or the funding of claims. Instead, the Directive introduces complex rules regarding access to information and joint and several liability. The new EU framework for antitrust damages actions is incoherent and unlikely to create the envisaged level playing field.
\end{abstract}

\section{INTRODUCTION}

Shakespeare's 'Much Ado About Nothing' elegantly combines comedy with more serious politics and embarrassment. The new EU Directive on Antitrust Damages that introduces measures to facilitate and balance damages actions in the EU Member States also joins these elements but rather less gracefully. Many of the provisions of the Directive are the result of a polemical and political process that lasted for more than a decade. The product is a mix of provisions, and not the coherent rules one had hoped for. Unlike Shakespeare's comedy, the Directive lacks any comical value, as it is soon to be translated into national law in 28 Member States. ${ }^{1}$ In this chapter, I will look closely at the key features of

\footnotetext{
* Lecturer in Law at the University of Leicester.

1 Directive of the European Parliament and of the Council on certain rules governing actions for damages under national law for infringements of the competition law provisions of the Member States and of the European Union,
} 
the reform of antitrust damages actions in the EU. As I will suggest, the new framework for EU damages actions is a seesaw between the two antithetical goals of the Directive: compensation and the coordination of enforcement.

\section{THE GOALS OF THE DIRECTIVE}

Article 1(1) of the Directive seeks to ensure more effective private enforcement actions by strengthening the right to compensation. Article 1(1) reflects the jurisprudence of the Court of Justice of the European Union (CJEU). The CJEU created an EU right to competition damages in its Courage and Manfredi judgments. ${ }^{2}$ According to these judgments, every individual should be able to claim compensation for loss caused by the breach of EU competition rules in the courts of the Member States. The Court also explained that:

In the absence of Community rules governing the matter, it is for the domestic legal system of each Member State to designate the courts and tribunals having jurisdiction and to lay down the detailed procedural rules governing actions for safeguarding rights which individuals derive directly from Community law, provided that such rules are not less favourable than those governing similar domestic actions (principle of equivalence) and that they do not render practically impossible or excessively difficult the exercise of rights conferred by Community law (principle of effectiveness) $[\ldots] .^{3}$

According to Article 1(2), the Directive also aims at coordinating effective public and private enforcement. Recital 6 clarifies that coordination refers to the interaction of public and private enforcement and its regulation, especially regarding access to information. In the context of the Directive, this means implementing safeguards to protect law enforcement by competition authorities in general, and to protect leniency programmes in particular. ${ }^{4}$

Over the past 15 years, the European Commission has subscribed to the popular view that private antitrust enforcement in the EU Member

adopted by the Parliament on 17 April 2014 and by the EU Council of Ministers on 10 November 2014 ('Damages Directive').

2 Case C-453/99 Courage Ltd v Bernard Crehan [2001] ECR I-6297; Case C-295/04 Vincenzo Manfredi v Lloyd Adriatico Assicurazioni SpA [2006] ECR I-6619.

3 Manfredi, cited previous note, para 62.

4 See Section IV below. 
States is underdeveloped and that claimants face considerable obstacles when pursuing antitrust damages claims in the courts. ${ }^{5}$ The Commission and other policy makers have measured the effectiveness of private antitrust enforcement in the number of successful damages claims. ${ }^{6}$ Consequently, compensation was declared to be one of the goals of this reform. In more recent years, beginning with the Commission's White Paper, the compensation objective has been complemented by the objective of coordination of public and private enforcement. ${ }^{7}$ This coordination aim is to be understood as a countervailing force to compensation, especially when private enforcement interferes with public enforcement activities. The proposition that these two enforcement modes can interfere with each other is not new, but the problems posed by private actions in Europe have become particularly obvious in recent years. Firms that sue or are planning to sue for compensation have begun to ask for access to information that is or was in the hands of the competition authorities, thus interfering with leniency programmes and settlement procedures. ${ }^{8}$ Both agencies and firms that submit evidence to the authorities clearly consider that this material should be treated as confidential and should not be disclosed to potential claimants. Hence, the new objective of coordinating public and private enforcement was introduced. ${ }^{9}$

This 'interaction' problem typically occurs in follow-on litigation, in other words, litigation running in parallel with public investigations or initiated after a decision has been adopted; it does not affect all antitrust damages litigation. One interpretation of the coordination objective is that national laws should refrain from encouraging follow-on actions.

5 See the Commission's earlier consultations: European Commission, 'Green Paper - Damages Actions for Breach of the EC Antitrust Rules', COM(2005) 672 final (19 December 2005); European Commission, 'White Paper on Damages Actions for Breach of the EC Antitrust Rules', COM(2008) 165 final (2 April 2008).

6 European Commission, 'Antitrust: Commission proposal for Directive to facilitate damages claims by victims of antitrust violations - frequently asked questions' (MEMO/14/310 of 17 April 2014); White Paper (cited previous note), at page 2. For a critical view of this benchmark, see Sebastian Peyer, 'Private Antitrust Litigation in Germany from 2005 to 2007: Empirical Evidence' (2012) 8 Journal of Competition Law and Economics 331.

7 See Recital 6 of the Damages Directive.

8 Case C-536/11 Bundeswettbewerbsbehörde v Donau Chemie AG, 6 June 2013, EU:C:2013:366; Case C-365/12 P Commission v EnBW Energie BadenWürttemberg AG, 27 February 2014, EU:C:2014:112.

9 White Paper (cited above note 5), at page 3; Damages Directive, Article 1(1). 
Such actions are more likely to interfere with investigations if, for example, potential claimants request information from the authority. The rules proposed in the Directive partly support this reading, as they do not facilitate follow-on actions as far as access to information is concerned but they do encourage stand-alone damages claims. ${ }^{10}$ If the Damages Directive indeed places limits on follow-on claims, then the two main aims of the Directive are mutually inconsistent. ${ }^{11}$ The compensation objective means fostering private actions, while the coordination objective demands restrictions on private claimants. The objective of effective compensation cannot be achieved without compromising the coordination objective, and vice versa. The effective coordination of public and private enforcement may thus be a euphemism for curtailing private enforcement when it interferes with agency activity. Overall, the two objectives are contradictory and have obscured the scope of the Directive. Its unclear scope, in turn, bears on several provisions.

\section{KEY FEATURES OF THE DAMAGES DIRECTIVE}

Before discussing certain aspects of the Directive in more detail in the following subsections, I will outline the general features contained in the Damages Directive. As will become obvious in this section, the Directive does not create a complete or coherent framework for damages actions in the Member States. It only addresses selected issues while avoiding politically sensitive and important problems: class litigation and litigation funding. Chapter I of the Directive states the scope of the Directive and provides some definitions in Article 2. Article 3 incorporates the Manfredi and Courage jurisprudence of the CJEU, articulating the right to compensation. ${ }^{12}$ Full compensation is achieved if the position of an injured individual is restored as if the infringement had not taken place. The Member States must ensure that a successful compensation claim includes redress for actual loss, loss of profits and the payment of interest. ${ }^{13}$

10 Articles 6 and 7 of the Damages Directive. Article 9 declares final (domestic) infringement decisions of a competition authority to be binding in private disputes, thus supporting follow-on litigation. Article 9 is discussed later in this chapter.

11 In a recent press release, the Commission stresses the lack of follow-on damages actions. See MEMO/14/310 (cited above, note 6).

12 The Courage and Manfredi judgments are cited above, note 2.

13 Article 3(2) of the Directive. 
Chapter II of the Directive deals exclusively with disclosure and access to information. Article 5 introduces disclosure of evidence in competition law damages proceedings in the courts of the EU Member States. The Directive then proposes, in Articles 7 and 8, a stricter test for disclosure of evidence that is included in the file of a competition authority. This narrower test limits the disclosure of information from competition authorities and excludes access to leniency statements and settlement submissions from general disclosure.

Chapter III of the Directive concerns three different issues. Article 9 declares final infringement decisions of competition authorities or review courts regarding EU and national competition law as binding (in the sense that a national court is precluded from adopting decisions running counter to such final decisions) and irrefutably established. This "binding" effect is limited to national decisions but foreign decisions are to be given the status of prima facie evidence, pursuant to Article 9(2). Article 10 regulates limitation periods. The minimum statutory period must be no less than five years from the time the infringement has ceased and the claimant knows or should reasonably have known about the infringement. In follow-on actions, the period of limitations must be suspended for the duration of a public investigation (Article 10(4)). In Article 11(1), the Directive requires the Member States to ensure that joint and several liability applies to companies that have jointly breached competition law. The principle of joint and several liability is relaxed, however, for smalland medium-sized enterprises and for leniency applicants that have been granted immunity. ${ }^{14}$ The exemption from joint and several liability does not apply to repeat offenders and ring leaders. Article 11 also limits contribution from an immunity recipient to its co-infringers so that the contribution does not exceed the harm it caused to its direct and indirect purchasers or providers. ${ }^{15}$

Articles 12 and 13 of Chapter IV of the Directive recognize the passing-on defence. Specifically, Member States must allow a defendant to show that the claimant did not actually suffer harm because the overcharge was passed on to the next level in the supply chain. Articles 14 and 15 of Chapter IV give indirect purchasers standing to sue. Every individual, independent of its position in the supply chain as direct or indirect purchaser, has the right to claim compensation. ${ }^{16}$ In this regard, the Directive facilitates the proof that part of the overcharge was passed 
on to indirect purchasers by introducing a de facto presumption of passing-on in follow-on damages cases. ${ }^{17}$ Defendants can rebut this presumption.

Finally, Article 17(1) of the Directive (Chapter V) allows courts to estimate the harm caused by competition law infringements where the available evidence does not permit a precise quantification of damages. Article 17(2) creates a presumption that the infringement caused harm but it does not provide any specificity with regard to the magnitude of the harm. In Chapter VI, out-of-court settlements are encouraged by providing for a suspension of the period of limitations (Article 18(1)) and for a limitation of the joint and several liability principle for settling defendants (Article 19).

Many of these rules relate to specific aspects of damages claims while others, such as the disclosure of information, are rather broad and will have a wide impact on the civil law systems in many Member States. In the next subsections, I will explore access to evidence issues, direct and indirect purchaser standing, and the rules of joint and several liability in more detail.

\section{ACCESS TO EVIDENCE}

Articles 5 to 8 of the Damages Directive deal extensively with access to information in antitrust damages actions. Article 5 encourages compensation claims by introducing disclosure of evidence in all antitrust damages actions in the courts of the Member States. The Member States must ensure that their courts are empowered to grant access to documents that are held by the defendants or third parties if the access-seeking party can reasonably justify why access is needed. In deciding on whether to grant a disclosure order, a court must use a proportionality test to weigh the interests in favour of and against disclosure. The court should consider the supporting material that underpins the access request, the scope and cost of disclosure, and whether the evidence that is to be disclosed contains confidential information. ${ }^{18}$ The Directive incorporates the recent jurisprudence of the Court of Justice and allows claimants to specify categories of documents to facilitate the disclosure procedure. ${ }^{19}$

Where the relevant conditions are satisfied, disclosure is available both to claimants bringing a damages claim independent of any investigation

\footnotetext{
17 Article 14(2).

18 Article 5(3).

19 See Donau Chemie and EnBW Energie, each cited above, note 8.
} 
by a public authority (stand-alone action) and to claimants pursuing a legal action for compensation that does relate to a public investigation (follow-on claim). Follow-on claimants can benefit from an ongoing or terminated agency case by requesting access to the agency's records. However, Article 6 of the Directive, which is largely driven by the objective of enforcement coordination, imposes strict limitations on the national courts regarding the disclosure of material included in the files of competition authorities. Article 7 extends the protection of information that has been acquired from the agency and is now in the hands of third parties or the defendants.

Article 6(6) 'blacklists' leniency and settlement submissions. These categories of documents enjoy 'absolute' protection from disclosure and cannot be revealed to access-seeking parties at any time (without prejudice to the possible application of Regulation 1049/2001, the 'Transparency Regulation', which could apply only in very narrow circumstances, if at all). Article 6(5) establishes a temporary blacklist. This closed category includes: (i) information that was specifically prepared for the proceedings of a competition authority; (ii) information the competition authority has drawn up and sent to the parties; and (iii) withdrawn settlement submissions. These types of materials are protected from disclosure requests until the competition authority has adopted a decision or otherwise terminated the proceedings. Moreover, requests for access to documents held by competition authorities are subject to a much stricter proportionality test. This stricter test for evidence in the possession of competition authorities applies to both non-blacklisted documents (which essentially means pre-existing documents) as well as temporarily blacklisted documents after the embargo period has expired.

The Directive's rules on the disclosure of evidence mark a turning point for many civil law jurisdictions. Unlike common law systems, civil law jurisdictions work with rebuttable presumptions and shift the burden of proof to encourage the production of evidence. A disclosure regime, such as that now imposed by the Directive, is alien to most civil law jurisdictions. This begs the question of whether a Directive specifically aimed at antitrust damages actions for the violation of EU competition law is the right instrument to initiate a potential reform of civil procedure in the Member States. The implications of these provisions in the Directive are far-reaching and should have been part of a more general Directive applicable to other areas of civil litigation as well. Theoretically, Member States could choose to apply these rules to 'EU' damages actions only ('EU' actions here meaning claims either based exclusively on EU competition law or where EU law and national law are applied by the court in parallel pursuant to Regulation 1/2003 on the 
ground that trade between Member States may be affected ${ }^{20}$ ), but it is more likely that they will allow disclosure in damages actions arising purely under national competition law as well and, possibly, they may even extend disclosure to other types of claims. For this reason it is problematic to use a narrowly focused Directive to reform civil litigation in the Member States. ${ }^{21}$

The provisions on access to documents also reflect the contradictory goals of the Directive. Article 5 creates a right to access and encourages disclosure, while Articles 6 and 7 limit access to agency information. The Directive discourages the use of crucial information held by the competition authorities and thus also discourages the bringing of follow-on claims. Follow-on claims will have to rely on the binding effect of final infringement decisions by the relevant national competition authority. ${ }^{22}$ However, the new framework does provide incentives to bring standalone claims, in other words, legal actions that are unrelated to agency investigations. Antitrust damages actions are more often than not follow-on cases, in other words, they are typically cases that are brought after the competition authority has unearthed potential evidence about wrongdoing or launched an investigation. ${ }^{23}$ In a deterrence model, follow-on actions increase the fine that is imposed on culpable firms but they do not increase the detection rate a great deal, as they rely on known infringements. ${ }^{24}$ On the other hand, follow-on actions create multiple issues regarding access to information contained in the files of competition authorities. Restricting access to information in follow-on actions reduces the incentives to bring such actions. The claim-encouraging binding effect of agency decisions in Article 9 is probably outweighed by the lack of information about the harm caused. This silent change of policy is to be welcomed, given that follow-on actions are an expensive

20 It follows from Article 4 and Recital 10 of the Damages Directive that the terms of the Directive apply to both purely EU law claims and combined EU law-and-national law claims.

21 A similar point is raised in Chapter 7 of this book.

22 Article 9 of the Directive.

23 Peyer, 'Private Antitrust Litigation in Germany from 2005 to 2007', cited above, note 6; Barry J. Rodger, 'UK Competition Law and Private Litigation' in Barry J. Rodger (ed), Ten Years of UK Competition Law Reform (Dundee University Press 2010) 53.

24 For a different view on private damages actions, see Robert Lande and Joshua Davis, 'Benefits From Private Antitrust Enforcement: An Analysis of Forty Cases' (2008) 42 University of San Francisco Law Review 879. The basic deterrence model is explained by Gary Becker, 'Crime and Punishment: An Economic Approach' (1968) 76(2) Journal of Political Economy 169. 
means to compensate victims. Redress schemes - such as, for example, those proposed in the UK - could be a more cost-efficient solution to promote the compensation of victims. ${ }^{25}$

\section{LIABILITY ISSUES}

The Directive also addresses liability issues relating to multiple defendants, making them jointly and several liable. The suggested framework is complex due to the designated exceptions; and it demonstrates once more the conflict between the compensation objective and the goal of coordinating public and private enforcement.

Article 11(1) holds co-infringers jointly and several liable, in other words, any defendant is liable for the whole amount of damage caused by the other co-infringing firms. The potential claimant is given a choice to sue one, some, or all infringers for the total amount of the loss that the claimant has suffered from the joint infringement. However, Article 11(2) deviates from the principle of joint and several liability. First of all, a small- or medium-sized company is only liable for the damage it has done to its direct and indirect purchasers if this firm has a market share of less than 5 per cent and if ' $[\ldots]$ the application of the normal rules of joint and several liability would irretrievably jeopardize its economic viability and cause its assets to lose all their value'. ${ }^{26}$ Ringleaders, repeat offenders or firms that have coerced others into participating in the illegal conduct cannot benefit from this exception. ${ }^{27}$ Neither the reasoning behind this exemption nor the wording of the rule is very clear. The exemption undermines the deterrence effect of potential damages actions for small- and medium-sized companies. It will also make litigation more complicated, as claimants do not know whether the exemption rule will apply to the defendant. Claimants will have to find out during the litigation process whether a small company can be held liable for the whole amount of loss. It may therefore reduce the incentives to sue small companies if the claimant thinks it is plausible that the defendant will not be liable for all the harm; and it may thus increase the risk and length of

25 The UK Consumer Rights Bill, which contains proposals regarding alternative dispute resolution, is currently being considered in Parliament.

26 Article 11(2)(b) of the Directive.

27 Ibid. 
legal proceedings. Whether that really matters in practice where, for example, most cartel members are being sued anyway, remains to be seen. ${ }^{28}$

Second, joint and several liability (and contribution) is further restricted in cases where the defendant receives full immunity from fines. Somewhat confusingly, Article 11(4)(a) states that immunity recipients shall be jointly and severally liable to their direct and indirect purchasers. This actually means that there is no joint and several liability for this category of defendants. The joint and several liability principle extends the liability of the defendant: it implies that he is responsible not only for harm caused by the defendant himself but also for harm his co-infringers have caused to the claimant. Article 11(4) states the opposite by limiting liability to the directly caused damage. Consequently, immunity recipients benefit from an exemption from joint and several liability. Immunity recipients will only be liable for other than directly caused harm if claimants are not able to receive full compensation from the other infringers (Article 11(4)(b)).

Third, settling defendants benefit from a similar exemption pursuant to Article 19(1). The claimant cannot sue a defendant that has settled with the claimant for the damage that was caused by other co-infringers. However, if the claimant is not able to recover from the remaining defendants, he will be able to sue the settling defendant for the remaining damage. Co-infringers cannot ask for contribution from defendants who have settled.

The rules governing joint and several liability make for a complicated arrangement and drawn-out litigation. A claimant has to sue all companies concerned other than the immunity recipient and/or settling defendant to find out if they can obtain full redress for the harm caused by other infringers. If compensation cannot be achieved, the claimant must then sue the immunity recipient or settling defendant. The potentially long period a claimant must wait to ascertain exactly which companies are the proper defendants reduces legal certainty for all parties. It furthermore decreases the number of potential defendants if, for example, a larger cartel consists of: two or three medium-sized companies which may potentially benefit from the liability limitation explained above; a settling defendant; or a leniency applicant that has

28 See, for example, National Grid Electricity Transmission Plc v ABB Ltd and others [2012] EWCA 869 (National Grid II). 
been granted immunity from fines. All of these potential defendants would benefit from one or another limitation, thus complicating the litigation.

Furthermore, the reasoning behind the exemption for immunity recipients is weak. The Damages Directive states that immunity recipients (in other words, first-in leniency applicants) mitigate the harm that could have been caused to claimants by revealing the breach of competition law. Their exposed position potentially makes them preferential targets for civil litigation. ${ }^{29}$ It is not clear why firms that have already received a discount of up to 100 per cent of the administrative fine should receive a second discount. Firms considering whether to blow the whistle will engage in a cost-benefit analysis before submitting evidence to the authority. Such firms are very likely to take exposure to civil liability into account. It is arguable that immunity recipients do not deserve protection from both administrative fines and damages claims. U.S. antitrust litigation shows that joint and several liability can be applied without a right of contribution, which to some extent facilitates the framework. According to Baker, contribution should be based on one simple and comprehensive formula. ${ }^{30}$ Neither the rules on joint and several liability nor the contribution rules are simple in the EU's new antitrust damages framework. Maybe the Directive should have followed the U.S. approach or, even better, it should perhaps have waited and regulated this issue for civil litigation in general. The current framework may need to be adjusted soon and, in the meantime, it is likely to lead to satellite litigation in the courts of the Member States.

\section{ISSUES RELATED TO STANDING TO BRING CLAIMS}

The final comment to be made here deals with the standing arrangements and the passing-on defence that are outlined in Articles 12 to 15 of the Directive. Article 12 grants both direct and indirect purchasers the right to sue for damages. More importantly, Article 14(2) creates a presumption that harm was passed on to indirect purchasers if: (a) the defendant has committed an infringement; (b) the infringement resulted in an overcharge for the direct purchaser; and (c) the claimant shows that he has purchased affected goods or services. The claimant will have few

\footnotetext{
29 Recital 38.

30 Donald I. Baker, 'Revisiting History - What Have We Learned About Private Antitrust Enforcement that We Would Recommend to Others' (2004) 16(4) Loyola Consumer Law Review 379, 388.
} 
difficulties proving (a) and (c), especially in follow-on cases where the affected products and services are named and the infringement is made public. It will be more difficult to convince the courts that the infringement resulted in an overcharge for the direct purchaser. This information is not normally in the defendant's domain, so the claimant has to rely on the competition authority or on disclosure of information from the direct purchaser. Depending on the interpretation of this rule, it may work as a de facto presumption of passing-on or as a serious barrier to litigation. In the spirit of the Directive, it is more likely that the courts will opt for a claimant-friendly approach.

The presumption of passing-on of harm may conflict with the passing-on defence which is allowed pursuant to Article 13. With the passing-on defence the defendant can show that the claimant has not suffered any damage because the overcharge has been passed on to the next level in the supply chain. ${ }^{31}$ This becomes interesting in cases where not all but only a certain percentage of the overcharge is affected. Assuming that the defendant is sued by both a direct and indirect purchaser, the defendant is likely to invoke the passing-on defence against the direct purchaser. He must therefore show that the claimant levied the overcharge on the indirect purchaser. ${ }^{32}$ At the same time, to defend himself against the claim of the indirect purchaser the defendant must rebut the de facto presumption and show that the claimant has suffered no harm. From an evidentiary point of view, the defendant is in a comparatively poor position to substantiate both the passing-on defence and the rebuttal of the passing-on presumption. A direct purchaser is in a much better position to shed some light on the issue. The Damages Directive takes this into account by stressing that the defendant may request reasonable disclosure from the claimant. ${ }^{33}$ However, additional disclosure requests raise the costs of litigation and may work as a disincentive for potential claimants. Furthermore, if the (direct purchaser and indirect purchaser) claims against the defendant are joined, he has to prove contradictory points in court. The proposed rule is awkward and complicated. It should be replaced by a presumption or estimation of the harm that is passed on to the next level of the supply chain.

31 The passing-on problem also poses difficulties for the calculation of harm. See Oxera and a multi-jurisdictional team of lawyers led by Dr Assimakis Komninos, 'Quantifying Antitrust Damages - Towards Non-binding Guidance for Courts (Study prepared for the European Commission)' (Luxembourg, 2009).

32 Article 13 of the Directive.

33 Ibid. 
Like the contribution rules, the provisions on standing and the passing-on defence lack coherence and will lead to drawn-out litigation (or early settlements). Even the authors of the Directive acknowledge that this may be too complicated. Article 15 grants national courts discretion to avoid instances of multiple liability, or no liability, due to the rules expressed in Articles 12 to 14.

\section{CONCLUSIONS}

The Damages Directive sends mixed signals to potential damages claimants. On the one hand, it introduces sensible rules such as, for example, the binding and prima facie effect of agency decisions in follow-on litigation. On the other hand, it has adopted complex rules with regards to liability, standing and access to information. Some provisions signal clear support for private antitrust damages actions, whereas others point to the protection of public enforcement. The Articles of the Directive reflect contradicting objectives and the protracted legislative process. Unfortunately, the Directive fails to create a coherent framework for damages claims in the national courts. ${ }^{34}$ Nor does it address the real issues for victims who have suffered losses from anticompetitive conduct: the provisions in the Directive do not introduce or harmonize tools to aggregate small individual claims (a subject covered in the next chapter of this book). The Directive also avoids the hot topic of litigation funding. If the assumption that underpins the reform holds true - not enough damages claims are being brought - then the Directive misses the target. None of the provisions reduces costs or helps claimants to overcome the cost problem for small claims. Especially regarding small individual losses, victims often deliberately forego compensation because it is rational to do so when the costs of litigation outweigh the potential benefits. To increase the number of claims in the courts (and again, assuming that this is a good policy goal), funding should be liberalized and claim aggregation be allowed. No rational consumer will sue for a loss of several Euros if he faces hundreds of thousands of Euros in legal expenses. These damages actions will only be brought if a representative can aggregate them.

Overall, the Directive lacks coherence, and it is not always clear why certain aspects are regulated while others are not even mentioned. The policy makers should have been clearer about the real goal of the

34 The authors of the Damages Directive unconvincingly claim that uneven rules lead to uneven enforcement. See Recital 7. 
Directive: the protection of public enforcement where it overlaps with private actions. At the moment, the Directive pursues two goals: compensation and coordination. This has caused some confusion and has led to conflicting provisions. The drawn out genesis of this Directive was underpinned by unsound assumptions, and the Commission's approach to private actions has suffered from a change of objectives during the process. Consequently, the Directive got stuck half-way between a sound common-law class-action litigation system and a civil law system of antitrust litigation.

The Directive is unlikely to fulfil the promises it has made. In many Member States, the courts and legislators are ahead of the Directive, either introducing class actions already ${ }^{35}$ or planning to do so in the near future. ${ }^{36}$ Some issues regulated in the Directive had already been settled at national level but may now have to be dealt with again, such as, for example, problems regarding access to information. ${ }^{37}$ Overall, the Directive is unlikely to encourage more claims because it does not lower the cost for litigation but instead creates expensive and ineffective means to achieve the compensation objective.

35 See, for example, Part 23a of the Danish Administration of Justice Act; Article 140 bis of the Italian Consumer Code; and the Dutch class action regime under Article 3:305a BW.

36 See the UK Consumer Rights Bill.

37 With regard to access to leniency materials held by a competition authority (in this case the European Commission), the UK High Court applied the CJEU's Pfleiderer test in National Grid II, cited above, note 28 (granting limited access). (That test was established in Case C-360/09 Pfleiderer AG v Bundeskartellamt [2011] ECR I-5161; see also Donau Chemie, cited above, note 8.) For German law, see Higher Regional Court of Hamm, decision of 23 November 2013 (1 VAs 116/13) (allowing the requesting court to access case files, including leniency applications). 